\title{
Touch gives new life: mechanosensation modulates spinal cord adult neurogenesis
}

R Shechter, K Baruch, M Schwartz and A Rolls

Molecular Psychiatry (2012) 17, 469; doi:10.1038/mp.2010.129

Correction to: Molecular Psychiatry (2011) 16, 342-352; doi:10.1038/mp.2010.116; published online 16 November 2010

Following the publication of the above article, the authors noted that Asya Rolls's name was not included as a co-corresponding author. The correct and complete author names appear above.

Asya Rolls's current affiliation: Stanford University, School of Medicine. Contact information: asyar@ stanford.edu

\section{Synaptic modulators Nrxn1 and Nrxn3 are disregulated in a Disc1 mouse model of schizophrenia}

SM Brown, SJ Clapcote, JK Millar, HS Torrance, SM Anderson, R Walker, A Rampino, JC Roder, PA Thomson, DJ Porteous and KL Evans

Molecular Psychiatry (2012) 17, 469; doi:10.1038/mp.2011.27

Correction to: Molecular Psychiatry (2011) 16, 585-587; doi:10.1038/mp.2010.134; published online 15 February 2011

Following the publication of the above article, the authors noted that some of the author affiliations are incorrect. Dr Clapcote is affiliated with the Institute of Membrane and Systems Biology, University of Leeds, Leeds, UK. Drs Thomson, Porteous and Evans are affiliated with Psychiatric Genetics, Medical Genetics Section, Centre for Molecular Medicine and Institute of Genetics and Molecular Medicine, Molecular Medicine Centre, Western General Hospital, University of Edinburgh, Edinburgh, UK and Centre for Cognitive Ageing and Cognitive Epidemiology, Medical Genetics Section, Molecular Medicine Centre, Western General Hospital, University of Edinburgh, Edinburgh, UK.

\section{Gestational immune activation and Tsc2 haploinsufficiency cooperate to disrupt fetal survival and may perturb social behavior in adult mice}

D Ehninger, Y Sano, PJ de Vries, K Dies, D Franz, DH Geschwind, M Kaur, Y-S Lee, W Li, JK Lowe, JA Nakagawa, M Sahin, K Smith, V Whittemore and AJ Silva

Molecular Psychiatry (2012) 17, 469-470; doi:10.1038/mp.2011.39

Correction to: Molecular Psychiatry (2012) 17, 62-70; doi:10.1038/mp.2010.115; published online 16 November 2010

Following the publication of this article, the authors noted that the TSC Natural History Database Project
Consortium should have been included within the Acknowledgments.

- Minnesota Epilepsy Group, P.A., St Paul, MN (Michael Frost, MD)

- Texas Scottish Rite Hospital for Children, Dallas, TX (Steven Sparagana, MD) 
- New York University Medical Center, New York, NY (Josiane LaJoie, MD)

- Massachusetts General Hospital, Boston, MA (Elizabeth Thiele, MD, PhD)

- Children's National Medical Center, Fairfax, VA (William McClintock, MD)

- University of Chicago, Chicago, IL (Michael Kohrman, MD)

- Oakland Children’s Hospital, Oakland, CA (Candida Brown, MD)

- UCLA Medical Center, Los Angeles, CA (Joyce T $\mathrm{Wu}, \mathrm{MD}$ )

- University of Texas, Houston (Hope Northrup, $\mathrm{MD)}$
- University of Alabama, Birmingham (E Martina Bebin, MD, MPA and Bruce Korf, MD, PhD)

- The Cleveland Clinic Foundation, Cleveland, $\mathrm{OH}$ (Ajay Gupta, MD)

- University of Colorado, Denver (Paul Levisohn, MD \& Susan Koh, MD)

- Miami Children’s Hospital, Miami, FL (Ian O’Neil Miller, MD and Michael Duchowny, MD)

- Loma Linda University Medical Center, Loma Linda, CA (Stephen Ashwal, MD)

- UZ Brussels Hospital, Brussels, Belgium (Anna C Jansen, MD, PhD)

- Pennsylvania Medical Center, Philadelphia, PA (Peter Crino, MD, PhD and Katherine Nathanson, MD)

\title{
Hierarchical temporal processing deficit model of reality distortion and psychoses
}

\author{
RR Krishnan, M Fivaz, MS Kraus and RSE Keefe
}

Molecular Psychiatry (2012) 17, 470; doi:10.1038/mp.2011.54

Correction to: Molecular Psychiatry (2011) 16, 129-144; doi:10.1038/mp.2010.63

Following the publication of this article, the authors noted that the funding information was incomplete.
It should be noted that Drs Richard Keefe and Michael Kraus received support for this work from the Translational and Clinical Research (TCR) Programme funding from the Singapore National Research Foundation to the Institute of Mental Health, Singapore.

\section{Converging evidence for central 5-HT effects in acute tryptophan depletion}

MJ Crockett, L Clark, JP Roiser, OJ Robinson, R Cools, HW Chase, H den Ouden, A Apergis-Schoute, D Campbell-Meiklejohn, B Seymour, BJ Sahakian, RD Rogers and TW Robbins

Molecular Psychiatry (2012) 17, 470; doi:10.1038/mp.2011.134

Correction to: Molecular Psychiatry (2012) 17, 121-123; doi:10.1038/mp.2011.106; published online 30 August 2011
Following the online publication of this article, the authors noted that Dr Campbell-Meiklejohn's name was misspelled. The complete and correct author names appear above. 